\title{
Peningkatan Mutu Asuhan Keperawatan Berbasis Patient Safety: Perspective Experience Pandemi Covid-19
}

DOI: https://doi.org/10.32509/abdimoestopo.v5i1.1751

\author{
Ernawati*, Wa Mina La Isa, Rusni Mato, M. Askar \\ STIKES Nani Hasanuddin Makassar \\ Jl. Perintis Kemerdekaan VIII No.24 Makassar, Indonesia 90245 \\ *Email Korespondensi: ernawati@stikesnh.ac.id
}

\begin{abstract}
Covid-19 has become one of the world's health problems since December 2019, and in Indonesia itself, on March 3, 2020, Covid was first confirmed in Indonesia. Since then, the morbidity and mortality rates in Indonesia have continued to grow and have an impact, especially on the order of health services. One of the efforts made by several hospitals in Indonesia is to improve the management of services for infected patients in general and COVID-19 patients in particular. Specifically for the nursing profession in handling patient safety, the points of attention of the hospital management are: Provision of WHO standardized PPE, Provision of infection rooms, Nursing HR settings (number, service shifts, overran shifts), Management of nursing care for COVID-19 patients, Quarantine protocols Nursing human resources, shift changes and quarantine at home. Because some of these problems require creative and innovative solutions, understanding, thinking and development. Based on this, the purpose of this service activity is to find out how to improve the quality of patient safetybased nursing care: perspective experience of the covid-19 pandemic. The results of the service that has been carried out through zoom on June 26, it was found that there was an increase in knowledge related to the quality of patient safety-based nursing care: perspective experience of the COVID-19 pandemic for health workers.
\end{abstract}

Keywords: Covid-19, Perspective experience, nursing care, quality improvement Nursing Care

Abstrak - Covid-19 menjadi salah satu masalah Kesehatan dunia sejak bulan Desember 2019 , dan di indonensia sendiri pertanggal 3 maret 2020 covid pertama kali terkonfirmasi di indonesia. Sejak itu, angka kesakitan di indonesia dan kematian diindonesia terus bertambah dan berdampak terutama pada tatanan pelayanan Kesehatan. Salah satu upaya yang dilakukan oleh beberapa Rumah Sakit di Indonesia sedang membenahi tata kelola pelayanan pasien infeksi pada umumnya dan pasien covid 19 secara khusus. Khusus untuk profesi keperawatan dalam penanganan patient safety yang menjadi titik perhatian pihak pengelola rumah sakit adalah : Penyediakan APD terstandar WHO, Penyediaan ruang infeksi, Pengaturan SDM Keperawatan (jumlah, shiff dinas, overran shiff), Tata kelola asuhan keperawatan pasien covid 19, Protokoler karantina SDM keperawatan, pergantian shiff dan karantina di rumah. Karena Beberapa permasalahan ini membutuhkan solusi, pemahaman, pemikiran dan pengembangan secara krestif dan inovatif. Berdasarkan hal tersebut maka tujuan kegiatan pengabdian ini adalah untuk mengetahui bagaimana peningkatan mutu asuhan keperawatan berbasis patient safety :perspective experience pandemi covid-19. Hasil pengabdian yang telah dilakukan melalui zoom pertanggal 26 juni adalah didapatkan bahwa adanya peningkatan pengetahuan terkait mutu asuhan keperawatan berbasis patient safety :perspective experience pandemi covid-19 bagi tenaga Kesehatan.

Kata Kunci: Covid-19, Perspective experience, asuhan keperawatan, Mutu Askep 


\section{PENDAHULUAN}

Sejak bulan Februari 2020 Indonesia dilanda Pandemi covid 19. Setelah beberapa Negara terlebih dahulu dilanda pandemi Covid 19, seperti Wuhan China, Italia, Spanyol dan Amerika. Covid 19 belum ada obat dan Immunisasinya, penularan sangat cepat melalui droplet Infaksi, dengan cara kontak langsung dengan Pasien Covid 19.Jumlah terpapar Covid 19 di Indonesia update 8 juni 2020 pukul 12.00 (gugus tugas covid 19 19, 2020) sebagai berikut ; ODP 38.791 , PDP 14.010, Positif 32.003, Sembuh 10.904, Meninggal 1.883. data dari 34 Provinsi, dan 422 Kabupaten / Kota. Pandemi covid telah memporakporandakan tatanan ekonomi, social dan pelayanan kesehatan di dunia, juga di Negara Indonesia. (Kilateng et al, 2018)

Upaya yang bisa dilakukan adalah menjalani cara-cara hidup bersih dan sehat. Jurus ampuh adalah : mencuci tangan memekai sabun sesiring mungkin, Memakai masker, jangan bepergian ketempat-tempat keramaian apabila tidak mendesak, Menjaga jarak dengan orang lain. Membawa dan memakai Handsanitizer bila bepergian, Mengganti pakaian dan segera mandi apabila habis bepergian di luar rumah. Menjaga asupan makanan bergizi seimbang, berjemur dibawah sinar matahari selama 30 menit (jam $09.00 \mathrm{sd} 11.00$ ). Tidak panik, takut dan stress, dengan tetap tenang, Tarik nafas dalam dan mencari informasi dengan benar hal ini untuk menjaga immunitas. Menjaga kebersihan dan kesehatan lingkungan (sampah ,air mengalir, kebersihan rumah). Tatanan pelayanan kesehatan paling terdampak dengan pandemic covid 19. Diperlukan kesiapan mental dan kompetensi bagi tenaga kesehatan termasuk perawat sebagai profesi terdepan dalam pelayanan kekesehatan. (KKP-RS, 2020)

Mutu pelayan keperawatan adalah tahapan derajat kesempurnaan dari pelayanan keperawatan yang membuat kepuasaan dari pasien dan keluargana, kelompok, komunitas dan masyarakat. Pelayanan keperawatan yang diberikan sesuai standar yang berlaku dan kepatuhan terhadap standar, sehingga membauat kepuasan (Anwar 20016). Peningkatan mutu pelayanan adalah derajat memberikan pelayanan secara efisien dan efektif sesuai dengan standar profesi, standar pelayanan yang dilaksanakan secara menyeluruh sesuai dengan kebutuhan pasien, memanfaatkan teknologi tepat guna dan hasil penelitian dalam pengembangan pelayanan kesehatan/keperawatan sehingga tercapai derajat kesehatan yang optimal. (Dedi, 2020).

Salah satu upaya yang dilakukan oleh beberapa Rumah Sakit di Indonesia sedang membenahi tata kelola pelayanan pasien infeksi pada umumnya dan pasien covid 19 secara khusus. Khusus untuk profesi keperawatan dalam penanganan patient safety yang menjadi titik perhatian pihak pengelola rumah sakit adalah : Penyediakan APD terstandar WHO, Penyediaan ruang infeksi, Pengaturan SDM Keperawatan (jumlah, shiff dinas, overran shiff), Tata kelola asuhan keperawatan pasien covid 19, Protokoler karantina SDM keperawatan, pergantian shiff dan karantina di rumah. Karena Beberapa permasalahan ini membutuhkan solusi, pemahaman, pemikiran dan pengembangan secara krestif dan inovatif.( Miake, et al, 2013).

Patient Safety atau Keselamatan pasien rumah sakit adalah suatu sistem di mana rumah sakit membuat asuhan pasien lebih aman. Sistem tersebut meliputi: asesment risiko, identifikasi dan pengelolaan hal yang berhubungan dengan risiko pasien, pelaporan dan analisis insiden, kemampuan belajar dari insiden dan tindak lanjutnya serta implementasi solusi untuk meminimalkan timbulnya risiko .( Miake, et al, 2013).

Terdapatnya indikator tentang jumlah kasus, jumlah yang meninggal, jumlah kesembuhan, jumlah pemeriksaan, jumlah tempat tidur di ruang isolasi, penurunan laju insiden dan penurunan angka kematian. Hal ini mendorong kesiapan rumah sakit dan fasilitas kesehatan dalam pemenuhan mutu layanan pada masa kenormalan baru yang berfokus pada dimensi pada pasien, adil, efisien, efektif, tepat waktu, aman dan terintegrasi. Adanya sistem keselamatan pasien/ pasient safety dengan merkomendasikan adanya sistem manajemen bencana, program penanggulangan bencana, standar PPI, fasilitas pelayanan kesehatan 
memastikan skrinning dan triage pada pasien dan pengunjung, penerapan kaidah K3, akses seluruh pengunjung, pemetaan area berisiko, supply chain management. Sehingga berperan perawat dalam penanggulangan Covid 19 di pelayanan kesehatan melalui kegiatan pengabdian kepada masyarakat dengan memberikan informasi dan edukasi yang memadai dengan tema Peningkatan mutu asuhan keperawatan berbasis Patient Safety; Perspective experience pandemi Covid-19 kepada mahasiswa dan tenaga kesehatan khususnya perawat di rumah sakit. Hal ini sejalan dengan pernyatan dilakukan oleh Brension Relly (2022) menyatakan bahwa 6 tema utama yaitu, a). Pengelolaan Sumber Daya Manausia Perawat, b). .Pengelolaan Keuangan, c). ketersedian bahan habis pakai, d).Kesiapan alat medis, e) Metode pengelolaan ruangan, f).evaluasi manajemen pengelolaan sumber daya manusia, keuangan, sarana, ketersedian alat, metode tata kelola ruangan. menyimpulkan bahwa pengelolaan dan evaluasi kepala ruangan selama pandemi Covid 19 perlu pengelolaan sumber daya manusia, keuangan, ketersediaan bahan habis pakai, alat dan metode tata kelola ruangan menjadi perhatian khusus para manajer rumah sakit yang melakukan pemberiaan layanan kesehatan kepada pasien Covid-19

\section{METODE PELAKSANAAN}

Metode yang digunakan pada pengabdian masyarakat kali ini terbagi menjadi tiga tahap, yaitu (1) Tahap persiapan, (2) Tahap pelaksanaan, dan (3) Tahap evaluasi. Tahap persiapan diawali dengan diadakannya persiapan untuk melaksanakan zoominar kepada tenaga kesehatan terkait peningkatan pengetahuan terkait mutu asuhan keperawatan berbasis patient safety :perspective experience pandemi covid-19. Pada tahap ini juga dilakukan persiapan terutama untuk jaringan yang akan di gunakan karena masalah jaringan sangat mempengaruhi dalam kelancaran berjalannya zoominar.

Tahap pelaksanaan pengabdian masyarakat melalui daring meliputi pembukaan webinar, penyampain materi, sesi tanya jawab, dan sebelum acara dimulai kuesioner akan disebar untuk mengetahui bagaimana pemahaman peserta terkait mutu asuhan keperawatan berbasis patient safety, dan di akhir zoominar akan di sebarkan lagi kuesioner (pre dan post).

Materi yang disampaikan pada webinar ini adalah terkait pemberian suhan keperawatan pada patient safety yang terdiri dari peningkatan mutu asuhan keperawatan terhadap Perspektif Experience Pandemi Covid-19, yaitu aplikasi kualitas layanan dengan menerapkan konsep "RATER" yang dikemukakan oleh Parasuraman, meliputi ; Responsiveness yaitu a) Memberikan penjelasan secara bijaksana sesuai dengan bentuk-bentuk pelayanan yang dihadapinya. Penjelasan bijaksana tersebut mengantar individu yang mendapat pelayanan mampu mengerti dan menyetujui segala bentuk pelayanan yang diterima. b) Memberikan penjelasan yang mendetail yaitu bentuk penjelasan yang substantif dengan persoalan pelayanan yang dihadapi, yang bersifat jelas, transparan, singkat dan dapat dipertanggungjawabkan. c) Memberikan pembinaan atas bentuk-bentuk pelayanan yang dianggap masih kurang atau belum sesuai dengan syarat-syarat atau prosedur pelayanan yang ditunjukkan.d) Mengarahkan setiap bentuk pelayanan dari individu yang dilayani untuk menyiapkan, melaksanakan dan mengikuti berbagai ketentuan pelayanan yang harus dipenuhi. e) Membujuk orang yang dilayani apabila menghadapi suatu permasalahan yang dianggap bertentangan, berlawanan atau tidak sesuai dengan prosedur dan ketentuan yang berlaku. Uraian-uraian di atas menjadi suatu interpretasi yang banyak dikembangkan dalam suatu organisasi kerja yang memberikan kualitas layanan yang sesuai dengan daya tanggap atas berbagai pelayanan yang ditunjukkan. Inti dari pelayanan daya tanggap dalam suatu organisasi berupa pemberian berbagai penjelasan dengan bijaksana, mendetail, membina, mengarahkan dan membujuk. Apabila hal ini dapat diimplementasikan dengan baik, dengan sendirinya kualitas layanan daya tanggap akan 
menjadi cermin prestasi kerja pegawai yang ditunjukkan dalam pelayanannya. Assurance yaitu Semua bentuk pelayanan kesehatan memerlukan adanya kepastian dan jaminan atas pelayanan yang diberikan. Bentuk kepastian dari suatu pelayanan keperawatan sangat ditentukan oleh jaminan dari perawat yang memberikan pelayanan keperawatan, sehingga pasien yang menerima pelayanan merasa puas dan yakin bahwa segala bentuk urusan pelayanan keperawatan yang berikan tuntas dan selesai sesuai dengan kecepatan, ketepatan, kemudahan, kelancaran dan kualitas layanan yang diberikan. Tangible yaitu kualitas layanan adalah bentuk aktualisasi nyata secara fisik dapat terlihat atau digunakan oleh perawat atau petugas kesehatan sesuai dengan penggunaan dan pemanfaatannya yang dapat dirasakan membantu pelayanan keperawatan dan atau kesehatan yang diterima oleh orang yang menginginkan pelayanan, sehingga puas atas pelayanan yang dirasakan, yang sekaligus menunjukkan kinerja bagi perawat atau tenaga kesehatan sebagi pemberian pelayanan keperawatan dan atau kesehatan kepada customer. Empathy dimana dalam suatu pelayanan keperawatan adalah adanya suatu perhatian, keseriusan, simpatik, pengertian dan keterlibatan pihak-pihak yang berkepentingan dengan pelayanan kesehatan untuk mengembangkan dan melakukan aktivitas pelayanan kesehatan sesuai dengan tingkat pengertian dan pemahaman dari masing-masing profesi. Reliability yaitu Setiap pelayanan memerlukan bentuk pelayanan yang andal, artinya dalam memberikan pelayanan, setiap pegawai diharapkan memiliki kemampuan dalam pengetahuan, keahlian, kemandirian, penguasaan dan profesionalisme kerja yang tinggi, sehingga aktivitas kerja yang dikerjakan menghasilkan bentuk pelayanan yang memuaskan, tanpa ada keluhan dan kesan yang berlebihan atas pelayanan yang diterima oleh masyarakat.hal ini sejalan dengan pernyatan yang dilakukan oleh Hani Ruh Dwi (2021) menyatakan bahwa untuk meningkatkan asuhan keperawatan pada patient safety perlu adanya tata kelola, SDM, dan Overan shiff yang efektif sehingga terciptanya asuhan keperawatan efektif.

Kendala dalam peningkatan mutu asuhan keperawatan terhadap Perspektif Experience Pandemi Covid-19 yaitu: a) Kendala dalam memberikan pelayanan yang sesuai dengan tingkat pengetahuan terhadap uraian kerjanya. b) Kendala dalam memberikan pelayanan yang terampil sesuai dengan tingkat keterampilan kerja yang dimilikinya dalam menjalankan aktivitas pelayanan yang efisien dan efektif. c) Kendala dalam memberikan pelayanan yang sesuai dengan pengalaman kerja yang dimilikinya, sehingga penguasaan tentang uraian kerja dapat dilakukan secara cepat, tepat, mudah dan berkualitas sesuai pengalamannya. d) Kendala dalam mengaplikasikan penguasaan teknologi untuk memperoleh pelayanan yang akurat dan memuaskan sesuai hasil output penggunaan teknologi yang ditunjukkan. Berdasarkan uraian tersebut di atas, maka dapat dipahami bahwa kualitas layanan dari keandalan dalam suatu organisasi dapat ditunjukkan keandalan pemberi pelayanan sesuai dengan bentuk-bentuk karakteristik yang dimiliki oleh pegawai tersebut, sesuai dengan keberadaan organisasi tersebut. Seorang pegawai dapat andal apabila tingkat pengetahuannya digunakan dengan baik dalam memberikan pelayanan yang andal, kemampuan keterampilan yang dimilikinya diterapkan sesuai dengan penguasaan bakat yang terampil, pengalaman kerja mendukung setiap pegawai untuk melaksanakan aktivitas kerjanya secara andal dan penggunaan teknologi menjadi syarat dari setiap pegawai yang andal untuk melakukan berbagai bentuk kreasi kerja untuk memecahkan berbagai permasalahan kerja yang dihadapinya secara andal.

Tahap Evaluasi pada tahap ini akan dilaksanakan evaluasi terhadap pemahaman peserta terkait mutu asuhan keperawatan berbasis patient safety dengan cara menyebarkan kuesioner terkait materi yang telah di berikan. 


\section{HASIL DAN PEMBAHASAN}

Pelaksaan pegabdian kepada masyarakat yang dilakukan melalui via daring dengan tema Peningkatan Mutu Asuhan Keperawatan Berbasis Patient Safety; Perspective Experience Pandemi Covid-19 di hadiri oleh 38 peserta dari berbagai Pendidikan yaitu D3 Keperawatan sebanyak 20 peserta, S1 Keperawatan 13 dan Ners 5 peserta.

\section{Distribusi Frekuensi berdasarkan Pendidikan, Usia dan Jenis Kelamin}

Tabel 1. Karakteristik peserta webinar

\begin{tabular}{llcc}
\hline No. & Karakteristik Responden & Jumlah & Persentase \\
\hline 1 & Tingkat Pendidikan & & \\
& D3 Keperawatan & 20 & $52 \%$ \\
& S1 Keperawatan & 13 & $34 \%$ \\
& Ners & 6 & $14 \%$ \\
& & & \\
\hline 2 & Usia & & \\
& 17- 25 tahun & 6 & $53 \%$ \\
& 26-35 tahun & 12 & $39 \%$ \\
& 36-45 tahun & 3 & $8 \%$ \\
& & & \\
\hline 3 & Jenis Kelamin & & \\
& Laki-laki & 15 & $39,4 \%$ \\
& Perempuan & 23 & $60,6 \%$ \\
& & & \\
\hline
\end{tabular}

Karakteristik responden penelitian lebih banyak yang berpendidikan D3 Keperawatan yaitu sebanyak 20 orang atau $52 \%$, sedangkan responden yang paling banyak berusia 26-35 tahun. Serta untuk jenis kelamin yang paling banyak adalah perempuan yaitu 23 orang atau $60,5 \%$.

\section{Distribusi Frekuensi Berdasarkan Pre dan Post Tes}

Tabel 2. terkait pengetahuan pre dan post

\begin{tabular}{ccccc}
\hline & \multicolumn{2}{c}{ Pre Test } & \multicolumn{2}{c}{ Post Test } \\
\hline Pengetahuan & Frekuensi (n) & Presentase (\%) & Frekuensi (n) & Presentase (\%) \\
Rendah & 3 & 30 & 0 & 0 \\
Tinggi & 7 & 70 & 10 & 100 \\
\hline Total & 10 & 100.0 & 10 & 100.0 \\
\hline
\end{tabular}

Distribusi Frekuensi Responden Berdasarkan Pre Test Dan Post Test menyatakan saat dilakukan pre test dengan jumlah soal 10 yang menjawab benar sebanyak 3 (30\%) dan menjawab salah sebnayak 7 (70\%), setelah dilakukan pemberian materi dan di berikan post test semua peserta menjawab 10 soal benar semua (100\%).

\section{Evaluasi Peningkatan Mutu Asuhan Keperawatan Berbasis Patient Safety}

Hasil pengabdian kepada masyarakat yang telah dilaksanakan pada bulan oktober tahun 2021 ini bahwa adanya peningkatan pengetahuan tenaga kesehatan terkait Peningkatan Mutu Asuhan Keperawatan Berbasis Patient Safety. Hal ini dibuktikan dengan hasil evaluasi yang telah dilakakukan dengan memberikan materi melalui zoominar dan 
pada akhir sesi, tim pelaksana menyebar kuesioner post test, dan dari beberapa jawaban responden yang lebih paham lagi terkait mutu asuhan keperawatan setelah dilakukan zoominar.

Patient safety atau Keselamatan pasien merupakan prioritas utama untuk dilaksanakan di rumah sakit dan hal tersebut terkait dengan isu mutu dan citra rumah sakit. Rumah sakit membutuhkan pengakuan dari masyarakat. Departemen Kesehatan R.I telah mencanangkan Gerakan Keselamatan Pasien Rumah Sakit sejak tahun 2005. Perhimpunan Rumah Sakit Indonesia (PERSI) menjadi pemprakarsa utama dengan membentuk Komite Keselamatan Pasien Rumah Sakit. Keamanan dan keselamatan merupakan kebutuhan dasar manusia, yang merupakan kebutuhan prioritas kedua setelah kebutuhan fisiologis pada Hirarki kebutuhan Maslow. Keamanan tidak hanya pencegahan kecelakaan dan injury tetapi juga mengijinkan seseorang untuk merasakan bebas dalam beraktivitas tanpa bahaya. Keamanan mengurangi stress, meningkatkan status kesehatan umum. Keamanan memungkinkan seseorang untuk memenuhi kebutuhan dasar mereka seperti dicintai dan mencintai dan harga diri dan memungkinkan seseorang mencapai kebutuhannya. Dampak positif dalam kehidupannya adalah menghasilkan status kesehatan mental yang lebih baik dan fungsi individu lebih efektif (Susanto, 2016).

Keamanan seringkali didefinisikan sebagai keadaan bebas dari cedera fisik dan psikologis, adalah salah satu kebutuhan dasar manusia yang harus dipenuhi. Lingkungan pelayanan kesehatan dan komunitas yang aman merupakan hal yang penting untuk kelangsungan hidup klien. Sehingga perlu adanya Review konsep dasar patien safety, Tata kelola pasien infeksi yang safety dan Implementasi patien safety dalam pelayanan keperawatan. Pernyataan ini sejalan dengan pernyataan oleh Sullivan et al (2020) menyatakan bahwa pengelolapelayanan keperawatan seorang pemimpin, seorang kepala ruangan mampu sebagai entrepreneur, decision maker, dan manajemen risk Mengutip dari tatnan ruangan pelayanan infeksi di rumah pada masa pandemi kepala ruangan memiliki peran dalam mengelola 7 aspek dimasa pandemi : a) Alur Proses Kegiatan Pelayanan, b) Zoning, Fungsi Ruang dan Tata ruang/Lay-out, c) Bentuk, Karakteristik \& Komposisi Bangunan, e) Jenis Konstruksi Bangunan dan Prasarana f) Program, Persyaratan \& Hubungan antar Ruangan, 6) Utilitas dan Fasilitas Penunjang, h) Ketersediaan danKualitas Alkes dan APD

Pelayanan patien covid 19 dari persfektif patien safety meliputi a). Penyedia ruang perawatan penyakit infeksi covid secara khusus, dengan tempat tidur, kamar, ruangan yang bisa di desinfentan setiap waktu.b). Ventilasi dan pencahayaan yang memadai, c). Terpisah dari ruangan perawatan pasien lainnya d). Tersedia sarana cuci tangan dan hands sanitizer yang memadai dan terstndar WHO, e). tata keloa ruang rawat infeksi covid 19, f). APD dan stardar operasional prosedur, g). Tata keloal SDM, h). Asuhan keperawatan Patisen Covid 19, i). Overan shiff yang efektif.

Berdasarkan hal tersebut sehingga tim pengabmas semakin yakin untuk tetap menyelenggarakan pengabmas ini untuk meningkatkan pemahaman tenaga kesehatan terhadap mutu asuhan keperawatan berbasis patient safety.

\section{SIMPULAN}

Hasil pengabdian kepada masyarakat yang dilakukan dengan tema Pelayanan asuhan keperawatan berbasis Patient Safety; Perspective experience pandemi Covid-19 dengan melakukan pretest pada peserta menemukan bahwa terdapat $70 \%$ tidak mengetahui penanganan Patient Safety saat masa pandemi, kemudian dilakukan edukasi serta diskusi terkait Penyediaan ruang perawatan penyakit infeksi covid secara khusus, dengan tempat tidur, kamar, ruangan yang bisa di desinfentan setiap waktu.b). Ventilasi dan pencahayaan yang 
memadai, c). Terpisah dari ruangan perawatan pasien lainnya d). Tersedia sarana cuci tangan dan hands sanitizer yang memadai dan terstandar WHO, e). tata keloa ruang rawat infeksi covid 19, f). APD dan stardar operasional prosedur, g). Tata keloal SDM, h). Asuhan keperawatan Patisen Covid 19, i). Overan shiff yang efektif, kemudian dilakukan postest hasil yang didapatkan sebesar $100 \%$ peserta pengabdian masyarakat memahami bagaiamana cara penanganan dengan metode asuhan keperawatan berbasis Patient Safety; Perspective experience dengan konsep aplikasi RATER, sehingga perlu adanya peningkatan pengetahuan tenaga Kesehatan terkait asuhan keperawatan berbasis Patient Safety Perspective experience untuk mewujudkan patient safety dibutuhkan upaya dan kerjasama berbagai pihak. Peningkatan Kesehatan pada Patient safety merupakan upaya dari seluruh komponen sarana pelayanan kesehatan yang memegang peran penting dalam tercapainya program Patient Safety. Sehingga saling berkesinambungan support system yang dibangun dalam melakukan asuhan keperawatan pada Patient safety meliputi Support sistem yang diperlukan perawat covid-19, mekanisme koping efektif, harapan yang diinginkan perawat dalam melakukan komunikasi terapeutik, pola hidup sehat agar dapat meminimalkan kejadian covid-19.

\section{Ucapan Terima Kasih}

Ucapan terimakasih kami haturkan kepada Yayasan Pendidikan Nani Hasanuddin Makassar yang telah memberikan support dan tidak lupa pula kami haturkan terimakasih pula kepada seluruh jajaran yang ada di STIKES Nani Hasanuddin Makassar. Adapun kami sampaikan ucapan terimakasih pula kepada seluruh pihak yang telah membantu dalam penyusunan ini hingga selesai.

\section{Daftar Pustaka}

Anwar. (2016), Kepemimpinan dan manajemen pelayanan keperawatan, Jakarta : UI Fress. Brension Relly, Yati Afiyanti, Muhammad Syafwani, 2022. Pengalaman Kepala Ruangan Dalam Mengelola Ruangan Yang Merawat Pasien Covid 19, https://jurnal.syntaxidea.co.id/index.php/syntax-idea/article/view/1717/1045, akses 20 januari 2022

Dedi. (2020). Kepemimpinan dan manajemen pelayanann keperawatan, Konsep, Teori dan Praktik Jakarta : Percetakan Tim

Hani Ruh Dwi (2021) Pengalaman Perawat Dalam Melakukan Komunikasi Terapeutik Pada

Klien Covid-19 Di Rsud H. Hanafie Muara Bungo Kabupaten Bungo Jambi Tahun 2020. 2021. Journal of TSCNers Vol.6 No.1 Tahun 2021 . file:///C:/Users/LENOVO/AppData/Local/Temp/275-341-1-PB.pdf, akses, 20 januari 2022

Kilateng, E. W. et al. (2018). Hubungan Pengetahuan Perawat Tentang Patient safety dengan Tindakan Pencegahan Risiko Pasien Jatuh di Ruang Interna RSUD Maria Walanda Maramis Airmadidi. E-Journal Sariputra Vol 2(2). Diakses pada tanggal 10 juni 2021dari http://jurnal.unsrittomohon.ac.id/index.php/ejurnal/article/viewFile/71/

KKP-RS. (2020). Pedoman Keselamatan Pasien Rumah Sakit Pusat Pertamina. Diakses pada $\begin{array}{llll}\text { tanggal } & 30 & \text { Juni }\end{array}$ darihttps://issuu.com/pramadya/docs/buku_pedoman_keselamatan_pasien_rspp publised on

Nursalam. (2010). Kepemimpinana dan Manajemen pelayanan keperawatan , Jakarta : EGC

Miake, I. M. et al. (2013). Inpatient Fall Prevention Programs as a Patinet Safety Strategy. a Sistematic Review : Annals of Interbal Medicine, Vol 158 No 5

Miake, I. M. et al. (2013). Preventing Falls in Hospitals : A Toolkit for Improving Quality of Care. Agency for Healthcare Research and Quality. 
Sullivan, Erin E., \& Phillips, Russell S. (2020). Sustaining primary care teams in the midst of a pandemic. Israel Journal of Health Policy Research, 9(1), 1-3

Sumarni. 2017 .Analisis implementasi patient safety terkait peningkatan mutu pelayanan kesehatan di Rumah Sakit. JNKI, vol.5 ,No.2

Simamora, R. H., \& Nurmaini, C. T. S. (2019). Knowledge of Nurses about Prevention of Patient Fall Risk in Inpatient Room of Private Hospital in Medan. Indian Journal of Public Health Research \& Development, 10(10), 759-763

Susanto, A. (2016). Gambaran Tingkat Pengetahuan Perawat tentang Program Patient Safety di Instalasi Rawat Inap Rumah Sakit Karya Bhakti Bogor. Diakses pada tanggal 17 Juni 2021 dari http://lib.ui.ac.id/naskahringkas/2016-03/S46217-Agus\%20Susanto. 